\title{
The Effectiveness of Family Planning Program Policies In Gunung Pangilun Sub District
}

\author{
Shelvy Haria Roza ${ }^{1}$, Puteri Fannya ${ }^{2}$ \\ \{shelvyhariaroza@ph.unand.ac.id ${ }^{1}$, puteri.fannya@esaunggul.ac.id² \\ Faculty of Public Health, Andalas University, Padang, Indonesia ${ }^{1}$, \\ Faculty of Health, Esa Unggul University, Jakarta, Indonesia ${ }^{2}$
}

\begin{abstract}
KB Village (Family Planning Village) is one of the strategic innovations to be able to implement the priority activities of the Population, Family Planning, and Family Development Program (KKBPK) by the National Population and Family Planning Agency (BKKBN). The purpose of this study was to identify the effectiveness of family planning program policies in Gunung Pangilun sub-district. This research is qualitative. Data were collected through in-depth interviews, document review, and observation. Key informants were five people who understood about the KB Village program selected by purposive sampling. Data were analyzed by thematic analysis. The results showed that community participation was high, and the effectiveness of the KB Village Program policy in Gunung Pangilun sub-district had run well. The commitment of the implementers and community was good in supporting the policy. The program had been well-disseminated. However, funding for cadre incentives has not well-allocated. The facilities and infrastructures are still not well-provided, such as house care, restrooms, and Indonesia Healthy Cards. The education on waste management also needed to be improved. It is expected that all parties can improve the implementation of the Family Planning Village program.
\end{abstract}

Keywords: KB village, effectiveness, participation

\section{Introduction}

Indonesia, as a developing country, cannot avoid the population problems. The main is the large population with a relatively high population growth rate. Family Planning (KB) with CPR (Contraceptive Prevalence Rate) indicator, which is the number of family planning and unmet need for family planning services as stated in MDG's 5b, which states the target in realizing reproductive health access for all in 2015. But until the end of 2015, of the set target of increasing the modern CPR method to $65 \%$ and reducing the unmet need for family planning services to $5 \%$ in 2015 is still far from the target. The low CPR rate is related to the high unmet need, which is $8.5 \%$ of the number of fertile age couples (PUS) has great potential for unwanted pregnancy (KTD). Therefore, family planning is a strategic effort to reduce MMR and IMR. 
According to the World Population Data Sheet (2013), Indonesia has a 2.6 Total Fertility Rate (TFR), Indonesia is still above the average TFR of ASEAN countries, which is 2.4. TFR will tend to increase if the use of contraception is not increased. The challenge for the government and the BKKBN is to reduce the TFR to others. Besides, differences in the acceptance of national policies in each region and limited budgets require thinking through strategies for working across sectors and using effective budgets for optimal family planning, and increasing community participation in synergizing family planning programs with conflicting community and religious views.

The population of Padang City from year to year always increases. It can be seen in the population indicator table of Padang City, where the population growth rate in 2017 was $96.6 \%$, with a population of 909 million people, and predicted in 2018 to reach 1 million people. (BPS, 2017) Padang City is one of the cities that has the highest population growth rate compared to the regencies in West Sumatra Province. In 2014-2015 the population growth rate in Padang City was recorded at $1.44 \%$. (BPS, 2017)

Among the strategic innovations is the Population, Family Planning, and Family Development Program (KKBPK) by the National Population and Family Planning Agency (BKKBN). It involves many sectors in collaboration with BKKBN, which includes institutions, partners, work, and stakeholders. It must be implemented from the lowest structure of government (following the prerequisites for determining the location of the family planning village) in all districts and cities is through the Family Planning Village Program. (BKKBN, 2015).

Therefore the provincial government has launched the Family Planning Village or Family Planning Village program in West Sumatera Province Governor Decree Number: 476/952/2017 regarding the Formation of the Integrated Team for Family Empowerment and Welfare Movement, Family Planning and Health in West Sumatra Province. The Government of West Sumatra Province, in collaboration with the West Sumatra Province BKKBN, formed the KB Village. Based on data obtained from the BKKBN, there are $11 \mathrm{~KB}$ villages in the city of Padang. (BKKBN, 2016). The total population of Padang Utara is 75869 people and is among the 3 highest population in all districts of Padang City. The number of active family planning participants in the Padang Utara subdistrict 4170 out of the three lowest active family planning achievements of 11 districts in the city of Padang. (BPS, 2016) Gunung Padang subdistrict was selected as a pilot village in the Padang City level in 2016. Gunung Pangilun subdistrict is one of the villages in the North Padang District. The area of the district is $8.08 \mathrm{Km} 2$ and has a population of 25,000 . Therefore, researchers are interested in researching the effectiveness of Village Family Planning Policy towards the acceptance of the concept of family planning in Gunung Pangilun subdistrict.

The research aims to analyze the factors that influence the effectiveness of the Family Planning Village Policy on the acceptance of the concept of family planning in the Gunung Pangilun Village in terms of implementation background, supporting aspects, aspects of the obstacles, and the results of implementing the Family Planning Village Policy.

\section{Method}

This type of research used in this study is a type of descriptive research with a qualitative approach. The research informants were the Head of the Family Planning Division of BKKBN Padang, the Coordinator of the PLKB KB Village in Padang City, the head of subdistrict 
Gunung Pangilun, and the head of the working group of the KB Village Subdistrict 12 Berok Gunung Pangilun. Data collection techniques using interviews, documentation study, and observation. The focus of this research is regarding the implementation of the KB Village Program and the level of community participation in the KB Village Program.

\section{Result}

\subsection{Implementation of the KB Village Program in the Gunung Pangilun}

The implementation of the KB Village Programme can be seen from the communication, resources, disposition, and bureaucratic structure associated with this program.

\subsubsection{Communication}

Submission of information about the $\mathrm{KB}$ village and its implementation is carried out through dissemination and training. The targets are related SKPDs, BKKBN ranks, lurah, and also the community. There are some obstacles at the beginning of the implementation. Among others is to change the mindset of the community to participate in the program. It is as revealed by the Head of the BKKBN KB in Padang:

"We have socialized the task of starting from its leader to the lower. Structures. We have 8 sections showing 8 family functions. We socialize it for 1 day."

"Guidelines such as technical guidelines and SOPs can be disseminated from the center through meetings or training."

And also revealed by the Village Chief of Gunung Pangilun:

"Indeed, the area in the KB village is the area. To understand the concept of the KB village is not easy. So we gradually. So we have to be brave, have to be steadfast, change their mindset that community involvement in development must be high. It's also a long time we give them an understanding of about 6 months.

\subsubsection{Resources}

The budget for the implementation of Kampung KB in 2018 is sourced from the State Expenditure Budget, the Regional Expenditure Budget, and the principal fund of thought. Besides, funds can be sourced from non-government organizations, related Regional Work Units, and Corporate Social Responsibility (CSR).

The budget for program implementing cadre incentives does not yet exist like other cadres. Moreover, operational funds for the village level for the implementation of the KB Village program have also not been budgeted. It was explained by the Head of the BKKBN KB Division in Padang City and the Village Chief of Gunung Pangilun Village:

"The 2018 budget comes from the 367 million from the state Expenditure Budget, the non-physical from The Regional Expenditure Budget, which is 880 million for Family Planning Operational Costs, and 150 million for the data house. It is for $12 \mathrm{~KB}$ 
villages in the city of Padang. This budget increased from 2017, and also in 2017, there were no Family Planning Operational Costs yet. "

"For funds, there are no funds in this sub-district. We are not regional work units. Only with no funds does not mean that we cannot move. First, if our activities are not too large, we can be self-reliant from the community or leaders. We also have activities whose funds are sourced from the basic funds of the regional legislative council. There are these activities that we ask the relevant regional work units. We make a letter. For example, our agricultural service needs what plants, seeds, we make letters. We propose for CSR too."

"Our hope for the KB Village activities is certainly the first we want the Tribina cadres to get paid. In Padang, all cadres have incentives, posyandu cadres have incentives, KB cadres have incentives, $R T R W$ has incentives, Empowerment for family welfare has incentives. We propose to the government to provide incentives for the local leader. Hopefully, it will convince them to participate in the program. Then we also suggest that this sub-district will be given a kind of fund for operations for the implementation of the KB Village program, at least for meetings."

Facilities and infrastructure are still minimal such as data houses that not all KB villages have. Facilities and infrastructure needed in the KB Pang Kampung of Gunung Pangilun Village, among others in the health sector, are the Indonesia Healthy Card and the Family Hope Program, latrines and sanitation, education about garbage banks, provision of waste banks, training in waste management, and sorting compost waste.

\subsubsection{Disposition}

The attitude of the government, namely the Padang City Government, in this case, the Mayor of Padang, highly appreciates the existence of this KB village program. It was followed by a positive attitude shown by the regional working unit by prioritizing the $\mathrm{KB}$ villages in their activities. The KB community in RW 12 Berok Gunung Pangilun also has a high level of enthusiasm. It is indicated by their willingness to donate part of the land for road construction in their neighborhood. It was mentioned by the Head of Gunung Pangilun Village and Coordinator of KB village Padang City::

"So there are 3 people involved in this KB village: the government, leaders, and the community. They must have the same vision."

"So the Padang city government is very appreciative of the KB village program. The proof is that all relevant regional work units are requested by the regional chairman to prioritize the activities of the regional device work unit for the KB village."

"They already feel they can benefit from the KB family. They are moving now, so we have no difficulties in carrying out the program. We can see the slum area has become more organized. They voulenteery donate their land without any payment. It indicates that the people know they need to participate in the government program to develop their community. Their mindset has changed." 
"But sometimes not all people can accept $K B$ village. For that, we need more advertisement."

\subsubsection{Bureaucratic Structure}

The Family Planning Program, in its implementation, has a legal basis, including Law Number 52 of 2009, on the development of Population and Family Development. In addition to the city level, the Padang City Government also regulates the Implementation of the KB Village Program through the Decree of the Mayor of Padang Number 274 in 2018 concerning Kelurahan Kampung KB in 2018 and the Decision of the Mayor of Padang Number 265 concerning the Family Planning Village Outflow Working Group.

\subsection{Community participation}

Community participation in carrying out activities in KB RW 12 Berok Gunung Pangilun Village is quite high. They are eager to develop their area, and they are happy and helped by the existence of this KB Village program. It was mentioned by the Village Chief of Mount Pangilun, the Chairman of the Working Group, and the Secretary of the Working Group:

"... they already feel that they can benefit from the KB village. They are moving now, so no difficulties anymore. One of the proofs was that the road in the area was small and ugly, now they have donated the land without compensation. It is almost 2 billion. Poor regions want to give land to the extraordinary government. What it means is, they understand that community participation must be high towards development so that the mindset has begun to change." (inf-2)

"When compared to before, it was far different. Now they have supported, why, because they feel the impact of this KB village. Their area gets a lot of training, help. What are their needs, such as sanitation, roads that have been noticed by the government? So their enthusiasm for work is high now. It used to be difficult, just cynical. If we come, why come here, what is this again? But if not now, if now I go there, those who ask. What the head of the village to do? What do you want to do?. So happy. "(Inf-2)

"We, as citizens, are very pleased with the existence of the KB Village program, at least we have come to understand and understand the KB program and reproductive health." (Inf-4)

"We were greatly helped by the training on understanding this $K B$ village. We became more understanding about what is population, what is family planning, reproductive health, family empowerment, education, health, child, and social protection." (Inf-5) 


\section{Discussion}

\subsection{Implementation of the KB Village Program in Gunung Pangilun Subdistrict}

\subsubsection{Communication}

Submission of information about the implementation of the KB Village program in Gunung Pangilun Subdistrict was carried out in 2 forms, namely socialization and training. The flow of program socialization in the ranks of the National Population and Family Planning Board is carried out in stages, starting from the Provincial Population and Family Planning, then to the Population and Family Planning of Padang, family planning counseling, and the community. Desimination in the form of meetings and meetings.

The dissemination of KB Village includes the head of the working group, secretary, treasurer, and 8 workgroup sections that show 8 family functions. The eight sections are religious section, social culture section, love section, protection section, reproduction section, socialization and education section, economy section, and environment section. Workgroup socialization is conducted in the form of training, which is held once a year.

Communication is a thing that determines the success of achieving the objectives of the implementation or implementation of a program/policy. Communication involves the process of delivering information or transmission, the clarity of the information, and the consistency of the information conveyed. Knowledge of what they do can run if the communication goes well so that every decision, policy, and regulation can work well [1].

Communication between the structural ranks of the National Population and Family Planning Board and the Regional Work Unit has been going well. During the beginning of the program, some problems evoked regarding the acceptance of the community. Later, after the community felt the benefits of the KB Village, they support the program and participate in the KB Village program.

It is different from research conducted by Merrynce and Hidir (2013) regarding the effectiveness of the implementation of the KB Village program in the Central Kuantan District [2]. The communication process between family planning officers and the community is still not effective. It is due to the lack of extension workers. Get around this deficiency, and communication is done through counseling activities carried out in the district or district health center. The rest of the information dissemination and socialization about family planning programs is carried out through the distribution of brochures or leaflets to each puskesmas and prosyandu to provide information about the implementation of family planning programs.

One factor that causes the communication process to run smoothly is that meetings are held regularly. The KB Village Working Group holds a meeting once a month to evaluate the activities that have been carried out. Deliberation forum and mini-workshops are held every 6 months. At the subdistrict level, in addition to coordination through official meetings, Gunung Pangilun Subdistrict also formed a Whatsapp group in Kampung KB to facilitate communication with stakeholders related to KB Village.

\subsubsection{Resources}

The budget for the $2018 \mathrm{~KB}$ Village program is sourced from the State Revenue and Expenditure Budget, the Regional Revenue and Expenditure Budget, and the main fund of 
thought. Besides, funding can be sourced from the relevant Regional Working Units and Corporate Social Responsibility.

The budget derived from the State Expenditure Budget for Family Planning Operational Assistance (BOKB) in 2018 amounts to 808 million rupiahs. The budget originating from the 2018 Regional Expenditure Revenues totals 367 million rupiahs. The pokir fund is 150 million, which is used to form the data house. (BKKBN Kota Padang, 2018).

The budget is the amount of money spent in a certain period to implement a program. Allocating the budget means the systematic distribution of funds based on the overall budget owned by the company to carry out the program [3].

Although funding for the KB Village program has been sufficient, in terms of budgeting, there are still shortages. The budget for Tribina program implementing cadre incentives does not yet exist like other cadres. The operational budget for the implementation of the $\mathrm{KB}$ Village program has also not been budgeted.

The availability of contraceptive devices and medicines, as well as other supporting facilities in the area of this KB village, has no problem being located close to Puskesmas Pembantu or Puskesmas. It is in line with research conducted by Mardiyono (2017), who found that supporting facilities such as contraceptive equipment and medicines, Jamkesda, Jamkesmas, and other supporting facilities were sufficient.

Specifically for the KB Village in Gunung Pangilun Subdistrict, the facilities needed include the Indonesia Health Card (KIS) and the Family Hope Program (PKH), latrines and sanitation, education about waste banks, provision of waste banks, training in waste management, and compost waste sorting.

\subsubsection{Disposition}

The attitude of the government, namely the Padang City Government, in this case, the Mayor of Padang, highly appreciates the existence of this KB village program. It was followed by a positive attitude shown by the regional work unit by prioritizing the $\mathrm{KB}$ villages in their activities. The KB community in RW 12 Berok Gunung Pangilun also has a high level of enthusiasm. It is one of them marked by their willingness to donate part of the land for road construction in their neighborhood.

It is in line with research by Merrynce and Hidir (2013), that the implementation of the KB program in Kuantan Tengah District is sufficient to be able to show a good attitude or disposition to program recipients, namely the community and especially women [2].

The disposition or attitude of the implementers of the policy is an important factor during the implementation of public policy. If the implementation of a policy is to be effective, then the policy implementers must not only know what will be done but also must have the ability to implement it, so that in practice there is no bias.

The clarity of directives and instructions given by policymakers becomes the basic capital for program implementers to be able to understand each of the steps that must be carried out in implementing the program. In addition, also in showing their attitude in the process of implementing the KB program, avoid negative prejudice to the recipients of the program. If negative perception comes, it may affect the implementing the KB program. Therefore to avoid the negative perception, the program must be carried out with responsibility. 


\subsubsection{Bureaucratic Structure}

The Family Planning Program, in its implementation, has a legal basis, including Law Number 52 of 2009, on the development of Population and Family Development. In addition to the city level, the Padang City Government also regulates the Implementation of the KB Village Program through the Decree of the Mayor of Padang Number 274 in 2018 about the Village of the Kampung KB in 2018 and the Decision of the Mayor of Padang Number 265 concerning the Family Planning Village Outflow Working Group.

The selection of regions to become $\mathrm{KB}$ villages is based on the proposals of each subdistrict submitted to the BKKBN of Padang City. The selected regional criteria for KB Village consist of the main criteria, regional criteria, and special criteria. The scope of the KB village area is RW. In the City of Padang in accordance with the Decree of the Mayor of Padang Number 274 of 2018 concerning KB Village Kampung in 2018, 11 KB Villages in 11 Subdistricts in Padang City. It follows the Padang Mayor Decree.

The bureaucratic structure that has been implemented in implementing the KB program is well available. It means that bureaucratic structures are available from the highest level, namely the province to the lowest level, namely the regions. This institutional availability is intended so that each designated institution has its duties and authority in carrying out the family planning program. The clarity of responsibilities and workload of each institution will make it easy for institutions to do their work [4].

\subsection{Community Participation for KB Village in Gunung Pangilun Subdistrict}

Community participation in carrying out activities in KB RW 12 Berok Gunung Pangilun Village is quite high. They are eager to develop their area, and they are happy and helped by the existence of this KB Village program. One form of community participation is to give away part of their land for road construction without compensation from the government. It proves that the community is very aware of advancing the area where they live. This result is in line with the Setiawati (2017) conducted in KB Village, which found that $78 \%$ of respondents stated that the guidance of the KB village was good, and $94 \%$ of respondents stated that they were active in implementing the KB Village program [5].

Participation is closely related to community empowerment. Community empowerment is considered successful or not seen from how community participation in the process. By looking at the community's participation in the community empowerment, we will know the condition of the community and what kind of mindset of the community. When the attitude of participation in the community has been awakened, it is seen that the development of community thought will be aware of their condition. Participation is a condition in which the community participates in the process of identifying problems, and how to handle them, what decisions or actions must be taken to deal with these problems.

\section{Conclusion}

The level of community participation in the KB village program in RW 12 Berok Gunung Pangilun is very good. The community is eagerly carrying out KB Village activities. The KB Village Program is very effective in accelerating both physical and human development in RW 12 Berok Gunung Pangilun. Infrastructure such as roads has been built since the KB Village Program. 


\section{References}

[1] Agustino, Leo. 2008. Dasar-dasar Kebijakan Publik. Bandung: Alfabeta.

[2] Merrynce., Hidir,A. 2013. Efektivitas Pelaksanaan Program Kampung Keluarga Berencana. Jurnal Kebijakan Publik volume 4 nomor 1 Maret 2013, hal 1-118

[3] Wahab, Solichin Abdul. 2012. Analisis Kebijakan: dari Formulasi Penyusunan ModelModel Implementasi Kebijakan Publik. Jakarta: PT Bumi Aksara.

[4] Mardiyono. 2017. Kampung KB Sebagai Upaya Pemberdayaan Masyarakat/Keluarga di Jawa Timur. Jurnal Cakrawala Vol 11 nomor 12 Desember 2017: 129-136

[5] Setiawati,E. 2017. Persepsi Masyarakat Terhadap Program Kampung Keluarga Berencanadi Kelurahan Pantoloan Boya Kecamatan Tawaeli. E-journal Geo Tadolako Untad 